\title{
STRATEGI DAKWAH PENDIDIKAN AGAMA ISLAM PADA KELOMPOK PENGAJIAN “BELAJAR DADI WONG ANGON” DI KABUPATEN NGAWI
}

\author{
Nur Nazhifah \\ Program Studi Pendidikan Agama Islam, Sekolah Tinggi Ilmu Tarbiyah Raden Santri Gresik \\ Email: nurnazhifahstit@gmail.com
}

\begin{abstract}
Abstrak
Penelitian ini bertujuan untuk (1) Memahami strategi dakwah Pendidikan Agama Islam pada kelompok pengajian "Belajar dadi Wong Angon" (2) Memahami faktor yang menghambat, dan (3) Memahami faktor yang mendukung strategi dakwah Pendidikan Agama Islam pada kelompok pengajian "Belajar dadi Wong Angon". Jenis penelitian yang digunakan adalah deskriptif kualitatif dengan pendekatan studi kasus. Hasil penelitian ini adalah (1) Strategi yang digunakan dalam proses dakwah Pendidikan Agama Islam pada kelompok pengajian "Belajar dadi Wong Angon" yaitu, pendidik terlebih dahulu memastikan kesiapan peserta didik dalam menerima materi dakwah, memberikan suasana belajar yang nyaman dan damai, menyampaikan materi menyesuaikan dengan kapasitas peserta didik, memberikan kesempatan bertanya dengan menggunakan media telepon reguler konferensi atau telewicara (2) Faktor yang menghambat dianggap tidak ada (3) Faktor yang mendukung adalah seluruh komponen yang saling memberikan dukungan langsung.

Kata Kunci : Dakwah, Pendidikan Agama Islam, Kelompok pengajian "Belajar Dadi Wong Angon".
\end{abstract}

\section{PENDAHULUAN}

Pendidikan Agama Islam merupakan usaha yang dilakukan oleh pendidik dengan cara membina dan mengasuh peserta didik agar dapat memahami kandungan ajaran agama Islam secara menyeluruh, menghayati makna tujuan yang pada akhirnya dapat mengamalkan serta menjadikan Islam sebagai pegangan hidup yang sesuai dengan tuntunan Rasulullah SAW yang ada pada AlQur'an dan Hadits. (Majid, 2004: 2) Karena pendidikan agama Islam adalah ilmu terapan yang diamalkan, maka dalam proses menyampaikan materinya tidak hanya sekedar teori, tetapi juga praktik yang berupa tuntunan berupa tauladan baik dari pihak pendidik. (Dradjat, 2006)

PAI sebagai suatu usaha untuk membina dan mengasuh peserta didik agar senantiasa dapat memahami kandungan ajaran Islam secara menyeluruh, menghayati makna tujuan yang pada akhirnya dapat mengamalkan serta menjadikan Islam sebagai pegangan hidup. Untuk menjadi manusia muslim yang seutuhnya, ada beberapa hal yang harus dilakukan masyarakat sebagai peserta didik yaitu dengan cara melaksanakan ajaran-ajaran agama Islam dengan baik dan benar, sehingga tercermin pada sikap dan tindakan dalam seluruh kehidupannya, dalam rangka mencapai kebahagiaan dan kejayaan hidup di dunia dan akhirat. (Pimay, 2005: 6) Agar dapat melakukan kegiatan tersebut, maka peserta didik harus memiliki bekal yaitu pendidikan agama Islam yang sesuai dengan tuntunan Rasulullah SAW yang ada pada Al-Qur'an dan Hadits. 
Menjamurnya kelompok pengajian saat ini menjadi tantangan serta peluang dalam berdakwah pendidikan agama Islam. Pasalnya, tidak sedikit ummat Islam dalam mempelajari keilmuan Islam tidak pada sumber atau referensi yang tepat, yang sesuai dengan Al-Qur'an dan Hadits, sehingga salah dalam memaknai isi ilmu-ilmu keislaman secara baik dan benar. Dengan pemahaman yang salah maka tentu dalam prakteknya juga salah. Hal ini tentunya sangat fatal karena tidak mampu mempraktekkan ilmu-ilmu keislaman dengan baik dan benar. Telah banyak contoh-contoh kasus yang terjadi di Indonesia yang disebabkan oleh pemahaman yang salah dalam memaknai Islam secara menyeluruh. Hal ini tentunya sebagai peringatan bagi umat Islam agar lebih berhati-hati mempelajari ilmu-ilmu keislaman maupun ilmu pendidikan agama Islam.

Dari berbagai permasalahan tersebut, Kelompok pengajian "Belajar dadi Wong Angon" merupakan kelompok pengajian dapat menjadi salah satu solusi dengan cara memberikan sumber pendidikan agama Islam dari sumber yang benar dan dapat dipertanggung jawabkan sesuai dengan tuntunan Rasulullah SAW yang ada pada Al-Qur'an dan Hadits. Selain itu, materi yang diberikan sangat lengkap sesuai dengan kebutuhan dan kapasitas para peserta didik berupa materi tentang arti, teori, panduan penerapan berupa tata cara dan adab yang disampaikan dengan lengkap dan utuh.

Kelompok pengajian "Belajar dadi Wong Angon" ini adalah kelompok pengajian yang terdiri dari pendidik dan para peserta didik dan memiliki tujuan untuk menyampaikan dakwah pendidikan agama Islam dengan strategi yang memudahkan para peserta didik di dalamnya untuk memahami materi yang disampaikan sesuai dengan tuntunan Rasulullah SAW yang ada pada Al-Qur'an dan As-Sunnah yang terkandung dalam Hadits. Kelompok ini adalah jalur pendidikan non formal yang dibentuk dengan sukarela oleh pendidik dan peserta didik. Adapun materi yang disampaikan meliputi pembahasan tentang pendidikan agama Islam yang menggunakan berbagai media dakwah sesuai dengan keadaan, kebutuhan, dan kapasitas peserta didik.

Dalam kelompok pengajian "Belajar dadi Wong Angon" ini menyampaikan dakwah pendidikan agama Islam dengan strategi yang unik dengan hasil yang efektif dan efisien. Pokok pembahasan materi dakwah pendidikan agama Islam pada kelompok pengajian "Belajar dadi Wong Angon" ini, dapat langsung ditentukan dan disampaikan oleh pendidik, bisa juga dari penyelesa ian permasalahan yang sedang terjadi dalam kehidupan nyata, juga dari pertanyaan para peserta didik. Jadi, untuk tema materi yang disampaikan sangat fleksibel dan tetap berhubungan dengan materi keagamaan. Dalam kelompok pengajian ini, tidak ada persyaratan khusus untuk anggotanya, tidak ada pengelompokan baik jenis kelamin, jenjang pendidikan formal yang telah ditempuh, gelar pendidikan formal, suku, pekerjaan dan lain-lain sehingga semua bebas belajar dan berdiskusi bersama dalam kelompok. artinya kelompok pengajian ini terbuka untuk umum. 
Keberagaman pada peserta didik yang ada dan tersebarnya jangkauan dakwah menjadikan anggota peserta didik juga tersebar di berbagai wilayah, juga banyaknya peserta didik yang bergabung hingga tak terhitung jumlahnya sehingga tidak semua anggota dapat berkumpul dalam satu tempat di waktu yang sama dalam setiap proses dakwah. Maka dari itu, untuk memudahkan proses dakwah agar dapat berjalan efektif, efisien dan mudah dijangkau peserta didik, pedidik memberikan kemudahan agar peserta didik dapat tetap dapat mengikuti dakwah pendidikan agama Islam.

Kemudahan yang diberikan pendidik diantaranya adalah peserta didik dapat memilih ruang dakwah dan media dalam mengikuti proses dakwah yaitu, dapat bertemu langsung di rumah pendidik, bertemu di tempat pertemuan yang ditentukan, aplikasi percakapan dan telepon koferensi. Jadi, peserta didik dapat memilih sesuai kemampuan peserata didik. Dari berbagai media yang digunakan dalam proses dakwah, peneliti memilih batasan obyek penelitian ini yaitu media telepon konferensi. Latar belakang peneliti memilih obyek ini karena dapat dijangkau oleh peserta didik yang tinggal di berbagai wilayah.

Dari pembahasan tersebut, penulis tertarik untuk mengadakan penelitian yang berjudul "Strategi Dakwah Pendidikan Agama Islam pada Kelompok Pengajian "Belajar dadi Wong Angon" di Kabupaten Ngawi" untuk memahami lebih dalam bagaimana strategi yang digunakan dalam berdakwah, faktor penghambat dan faktor pendukung dalam proses dakwah proses dawah pendidikan agama Islam.

\section{METODOLOGI}

Pendekatan penelitian yang digunakan dalam penelitian ini adalah kualitatif. Penelitian kualitatif menurut Moleong (2013), adalah penelitian yang bermaksud untuk memahami fenomena tentang apa yang dialami oleh subjek penelitian, misalnya perilaku, persepsi, motivasi, tindakan dan lain-lain, secara holistik, dan dengan cara deskripsi dalam bentuk kata-kata dan bahasa pada suatu konteks khusus yang alamiah dengan memanfaatkan berbagai metode alamiah. Sedangkan jenis penelitian yang digunakan dalam penelitian ini, menggunakan jenis penelitian studi kasus yang merupakan penelitian yang diarahkan untuk membahas gejala-gejala, fakta-fakta, atau kejadiankejadian secara sistematis dan akurat, menggunakan sifat-sifat populasi atau daerah tertentu. (Riyanto, 2001: 79)

Lokasi penelitian ini berada di masing-masing tempat tinggal pendidik maupun peserta didik, karena dalam proses pengumpulan data penelitian ini dilakukan dengan menggunakan media telepon konferensi. Sedangkan untuk lokasi pendidik berada di tempat tinggal pendidik yang ada di Kabupaten Ngawi, Provinsi Jawa Timur. Pada penelitian ini, sumber data penelitian berasal dari 
salah satu kelompok kecil dengan menggunakan media telepon konferensi pada kelompok pengajian "Belajar dadi Wong Angon". Kedudukan peneliti dalam penelitian kali ini adalah pelaksana penelitian sekaligus peseta didik pada kelompok pengajian “Belajar dadi Wong Angon”.

Pada penelitian kualitatif pada dasarnya teknik pengumpulan data yang digunakan adalah observasi partisipan, wawancara mendalam, dan dokumentasi. Kegiatan pengumpulan data yang dilakukan dengan observasi dan wawancara mendalam untuk menjelajahi dan melacak sebanyak mungkin realitas fenomena yang tengah di studi. (Bungin, 2005: 93) Dalam pengumpulan data, peneliti mengadakan observasi, wawancara, materi audio dan laporan wawancara mendalam yang didapatkan dari pendidik dan peserta didik kelompok pengajian "Belajar dadi Wong Angon". Analisis data dalam penelitian kualitatif dilakukan pada saat pengumpulan data berlangsung, dan setelah selesai penumpulan data dalam periode tertetu. Pada saat wawancara, peneliti sudah melakukan analisis terhadap jawaban yang diwawancarai. Bila jawaban belum memuaskan. maka peneliti akan melanjutkan pertanyaan lagi, sampai tahap tetentu dan memperoleh data yang dianggap akurat.

\section{HASIL DAN PEMBAHASAN}

Penelitian ini fokus meneliti salah satu bagian dari kelompok kecil pada kelompok pengajian "Belajar dadi Wong Angon" yang dilakukan menggunakan media telepon konferensi. Karena dalam kelompok ini terdiri dari banyak peserta yang tidak terhitung, baik yang bertemu langsung dengan pendidik, maupun yang menggunakan media aplikasi percakapan maupun telepon konferensi, maka peneliti mengambil satu bagian kelompok kecil yang menggunakan media telepon konferensi untuk diteliti, yang tediri dari satu pendidik dan sepuluh peserta didik dengan rincian narasumber sebagai berikut :

Tabel 1. Daftar nama kelompok kecil pengajian "Belajar dadi Wong Angon"

\begin{tabular}{|c|l|l|}
\hline No & \multicolumn{1}{|c|}{ Nama } & \multicolumn{1}{|c|}{$\begin{array}{c}\text { Kedudukan dalam } \\
\text { kelompok pengajian }\end{array}$} \\
\hline 1 & Bapak Toni & Pendidik / Da'i \\
\hline 2 & Mbak Nur Nazhifah & Peserta pengajian \\
\hline 3 & Mas Fathul Hidayat & Peserta pengajian \\
\hline 4 & Gus Panjar Tumewu & Peserta pengajian \\
\hline 5 & Gus Waringen Jati & Peserta pengajian \\
\hline 6 & Gus Beghawan Lumintir Jagad & Peserta pengajian \\
\hline 7 & Gus Senopati Lukas Tambuaran & Peserta pengajian \\
\hline 8 & Gus Umam & Peserta pengajian \\
\hline 9 & Bapak Kirman & Peserta pengajian \\
\hline 10 & Bapak Yasa' & Peserta pengajian \\
\hline 11 & Mbak Nafi'ah & Peserta pengajian \\
\hline
\end{tabular}


Latar belakang terbentuknya kelompok pengajian "Belajar dadi Wong Angon”, yaitu dimulai adanya percakapan secara langsung antara pendidik dan peserta didik yang membahas tentang materi keislaman. Seiring berjalannya waktu, peserta dalam kelompok ini semakin bertambah banyak dan tersebar di Indonesia. Kelompok pengajian ini memiliki tujuan agar dapat mengamalkan ajaran agama Islam secara kaffah. Adapun sumber baca yang di gunakan oleh sebagai pedoman da'i atau pendidik dalam menyampaikan materi dalam proses dakwah pendidikan agama Islam pada kelompok pengajian "Belajar dadi Wong Angon” menggunakan sumber referensi dari Al-Qur'an dan Hadits.

Berdasarkan hasil observasi, kelompok ini memiliki peserta yang heterogen dan majemuk dari latar belakang yang berbeda-beda mulai dari jenis kelamin, tempat tinggal, berapa lama sudah mengikuti pengajian dan berbagai aspek lain, termasuk perbedaan daya tangkap terhadap materi dakwah yang disampaiakan oleh pemateri. Oleh sebab itu pendidik diharapkan agar dapat menyampaikan materi dengan strategi yang sesuai dengan ke mampuan atau daya tangkap yang dimiliki oleh peserta pengajian, sehingga peserta pengajian dengan mudah memahami materi dan mengimplementasikan dalam kehidupan sehari-hari.

Dalam mencapai tujuan dakwah pendidikan agama Islam, diperlukan strategi agar materi dapat tersampaikan dengan baik, adapun strategi yang digunakan dalam kelompok pengajian “Belajar dadi Wong Angon” ini diantaranya adalah :

1. Pendidik dapat menyesuaikan dengan keadaan dan kapasitas peserta didik.

Dalam hal ini, pendidik yang memiliki perwatakan yang kharismatik telah memahami kondisi fisik maupun psikis, sehingga dapat mengetahui seberapa kesiapan peserta didik dalam menerima materi yang akan diberikan. Selain itu, pendidik juga memperhatikan kapasitas peserta didik dalam menerima materi. Setiap peserta didik memiliki keunggulan yang berbeda-beda dalam setiap bidang dan memiliki kecepatan daya tangkap berbeda, sehingga pendidik perlu mengukur dan menerapkan cara yang sesuai dengan kebutuhan saat menyampaikan materi.

Selain itu, peserta didik juga berasal dari berbagai wilayah di Indonesia, sehingga pendidik menyesuaikan dari segi bahasa agar bahas yang digunakan mudah dipahami oleh peserta didik. Dalam ruang ini, pendidik juga mengajarkan toleransi dan saling membantu kepada semua, sehingga suasana dalam kelompok pengajian menjadi kondusif, nyaman, damai dan fleksibel agar materi proses dakwah pendidikan agama Islam dapat tersampaikan dengan efektif dan efisien serta bersifat fleksibel. 
2. Peserta didik memiliki ruang bebas bertanya.

Dalam proses dakwah pendidikan Islam, pendidik memberikan ruang bebas bertanya yang adil kepada seluruh peserta didik dengan keragaman yang ada, sehingga secara tidak langsung peserta didik juga dilatih percaya diri untuk tampil berani dan menyampaikan pertanyaannya dengan santun dan saling menghormati. Dari pertanyaan yang berasal dari peserta didik itu, pendidik dapat menjawab langsung pada proses dakwah pendidikan agama Islam tersebut dengan lengkap dan utuh, juga memastikan bahwa peserta didik dapat memahami jawaban yang telah disampaikan. Pendidik juga memberikan ruang bagi peserta didik lain yang dapat menjawab pertanyaan tersebut agar dapat terlatih menyampaikan apa yang telah dipahami dengan tetap ada kontrol yang dipandu dan dibantu oleh pendidik.

3. Tema materi keagamaan yang disampaikan bersifat fleksibel.

Tema materi yang disampaikan mencakup seluruh bab materi agama Islam yang dapat ditentukan langsung oleh pendidik, juga dapat diajukan oleh peserta didik melalui pertanyaan. Dari cara penentuan tema materi tersebut, maka dapat disimpulkan bahwa pendidik telah menguasai materi keagamaan dengan baik dan disampaikan dengan lengkap dan utuh. Dalam menyampaikan materi, pendidik menerangkan dengan sejelas-jelasnya dan langsung memberikan contoh-contoh pada ruang lingkup penerapan dalam kehidupan dengan lengkap dan sederhana, sehingga peserta didik dapat mudah memahami dan menerapkan langsung dalam kehidupannya.

Dasar hukum materi yang disampaikan adalah Al-Qur'an dan Hadits yang dikemas menarik dengan kearifan lokal dan sesuai dengan kebutuhan dan kapasitas peserta didik. Jadi, pendidik juga dapat menggunakan karya seni lokal sebagai salah satu cara dalam menyampaikan materi agar dapat diterima dengan santai dan tidak kaku, juga sebagai cara mengajarkan kebudayaan yang dapat dijadikan hiburan dengan tetap mengikuti normanorma yang ada. Dari cara tersebut, peserta didik menerima materi dengan rileks, sehingga materi mudah untuk dipahami dan proses dakwah pendidikan agama Islam terlaksana dengan efektif dan efisien.

4. Menggunakan media yang terjangkau.

Dalam kelompok pengajian "Belajar dadi Wong Angon" ini terdiri dari banyak peserta didik yang beragam dan tersebar di berbagai wilayah di Indonesia, yang berawal dari perbincagan tatap muka dengan pendidik. Seiring berjalannya waktu, jumlah peserta didik semakin banyak dan tidak terhitung. Oleh karena itu, pendidik menyediakan berbagai ruang untuk melangsungkan proses dakwah pendidikan agama Islam. Ruang-ruang itu adalah dapat bertemu langsung atau tatap muka, menggunakan aplikasi percakapan yang 
menggunakan jaringan internet, juga menggunakan telepon konferensi yang dapat menggabungkan banyak kontak peserta didik dalam satu panggilan.

Dalam penelitian ini, peniliti fokus dengan salah satu kelompok kecil yang menggunakan media telepon konferensi. Pada media yang digunakan untuk melangsungkan proses dakwah pendidikan agama Islam, pendidik dan peserta didik ini merupakan salah satu pemanfaatan teknologi yang ada yaitu dengan menggunakan telepon konferensi yang dapat dipakai pada telepon yang sederhana hingga telepon yang lebih canggih. Telepon konferensi menggunakan pulsa reguler dengan harga yang terjangkau dengan sinyal dan kualitas panggilan yang bagus, sehingga dengan alat yang mudah didapatkan dan biaya yang terjangkau sudah dapat dilaksanakan proses dakwah pendidikan Islam

5. Evaluasi mendalam dengan panduan lengkap.

Setelah menyampaikan proses dakwah pendidikan Islam, pendidik juga mengadakan evaluasi terhadap hasil dari proses proses dakwah pendidikan Islam yang sudah terlaksana. Evaluasi ini dapat dilakukan oleh pendidik dengan cara bertanya langsung kepada peserta didik tentang pemahaman materi yang telah disampaikan, juga dapat berupa pengamatan perubahan dan pengaruh terhadap perubahan perilaku peserta didik. Jika masih ada kendala atau pertanyaan dari peserta didik, maka pendidik menjelaskan kembali materi yang perlu disampaikan kembali hingga tuntas.

Dari strategi yang telah diterapkan, terbukti telah efektif dan efisien dalam proses penyampaian dakwah pendidikan agama Islam pada kelompok pengajian "Belajar dadi Wong Angon". Pendidik dan peserta didik juga nyaman dan menikmati proses dakwah pendidikan agama Islam dalam kelompok pengajian. Peserta didik juga dapat menerima dan memahami materi dengan baik dan menerapkan dalam kehidupan sehari-hari.

Dalam proses dakwah pendid ikan agama Islam pada kelompok pengajian "Belajar dadi Wong Angon" relatif berjalan lancar, tetapi ada beberapa kendala yang kadang terjadi diantaranya adalah terputusnya panggilan konferensi oleh salah satu atau beberapa anggota dalam proses berlangsungnya dakwah pendidikan Islam. Hal ini disebabkan oleh beberapa faktor, yaitu terkadang terjadi ketidakstabilan sinyal pada daerah tertentu. Tetapi hal itu sangat jarang terjadi karena pendidik dan peserta didik menggunakan layanan pada operator yang sama dan memiliki kualitas sinnyal yang baik dengan tarif biaya layanan yang relatif murah sehingga mudah dijangkau oleh seluruh anggota telepon.

Selain itu ada beberapa kendala lain yaitu panggilan tiba-tiba terputus karena pendidik atau peserta didik kehabisan pulsa dan kehabisan baterai. Untuk kendala kehabisan pulsa dapat diatasi 
dengan dibantu oleh pendidik atau peserta didik untuk dapat bergabung kembali ke dalam panggilan. Sedangkan untuk kehabisan baterai, peserta didik dapat mendapatkan materi yang tertinggal pada kesempatan panggilan berikutnya. Terkadang dapat diberikan rekaman proses telepon yang terlewat. Ada kendala lain juga yaitu terputusnya panggilan karena di lokasi pengguna telepon sedang cuaca buruk atau membahayakan jika melangsungkan panggilan sehingga terpaksa tidak mengikuti.

Dari berbagai kendala yang ada telah dapat diatasi dengan baik oleh pendidik dan peserta didik sehingga kendala tersebut tidak dianggap sebagai faktor penghambat tetapi dianggap sebagai perjalanan dari proses yang harus diperjuangkan sebagai perjuangan bersama untuk menyampaikan dakwah pendidikan agama Islam.

Untuk dapat terlaksananya proses dakwah pendidikan agama Islam dengan baik, tidak terlepas dari faktor yang mendukung. Diantaranya adalah :

1. Adanya saling mendukung dan memberikan semangat antara pendidik dan peserta didik.

Dari saling mendukung antara pendidik dan peserta didik, maka motivasi untuk mempelajari pendidikan agama Islam akan lebih tinggi, sehingga dengan kesadaran diri dan tanpa paksaan, peserta didik dengan sendiririnya memiliki kemauan dan semangat yang tinggi.

2. Tidak adanya yang merusak suasana belajar dan terjadinya kedamaian dan kenyamanan dalam proses dakwah.

Dalam kelompok belajar ini terdiri dari berbagai peserta didik yang beragam dan berasal dari berbagai wilayah di Indonesia, tetapi dari keberagaman itu pendidik dan peserta didik dapat saling menghargai dan menghormati sehingga terbentuknya kondisi yang nyaman. Dari kondisi tersebut maka tidak adanya oihak yang mengganggu, karena semua komponen dapat saling menghargai dan menghormati dengan baik.

3. Seluruh komponen yang ada, baik dari dalam maupun dari luar yang memberikan dukungan dan memberikan kemudahan pada kelangsungan proses dakwah pendidikan agama Islam.

Dari strategi dan kondisi yang ada di kelompok maka terciptanya kondisi proses dakwah pendidikam agama Islam yang kondusif dan nyaman, maka otomatis akan terwujudnya kemudahan terlaksananya proses pendidikan agama Islam.

\section{PENUTUP}

\section{Kesimpulan}

1. Strategi dakwah pendidikan agama Islam pada kelompok pengajian "Belajar dadi Wong Angon" meliputi :

a. Pendidik dapat menyesuaikan dengan keadaan dan kapasitas peserta didik. 

b. Peserta didik memiliki ruang bebas bertanya.
c. Tema materi keagamaan yang disampaikan bersifat fleksibel.
d. Menggunakan media yang terjangkau.
e. Evaluasi mendalam dengan panduan lengkap.

2. Kendala yang ada tidak dianggap sebagai faktor penghambat karena sudah dianggap sebagai perjalanan dari proses yang harus diperjuangkan dalam menyebarkan dakwah pendidikan agama Islam.

3. Faktor pendukung dakwah pendidikan agama Islam kelompok pengajian "Belajar dadi Wong Angon" meliputi :

a. Adanya saling mendukung dan memberikan semangat antara pendidik dan peserta didik.

b. Tidak adanya yang merusak suasana belajar dan terjadinya kedamaian dan kenyamanan dalam proses dakwah.

c. Seluruh komponen yang ada, baik dari dalam maupun dari luar yang memberikan dukungan dan memberikan kemudahan pada kelangsungan proses dakwah pendidikan agama Islam.

\section{DAFTAR RUJUKAN}

Majid, Abdul. Andayani, Dian. 2004. Pendidikan Agama Islam Berbasis Kompetensi (Konsep dan Implementasi Kurikulum 2004). Jakarta. Remaja Rosda Karya.

Moeleong, Lexy J. 2013. Metodologi Penelitian Kualitatif. Bandung. PT. Remaja Rosdakarya.

Riyanto, Yatim .2001. Metodelogi Penelitian Pendidikan. Surabaya. SUC.

Bungin, Burhan. 2005. Analis is Data Penelitian Kualitatif. Jakarta. PT. Raja Grafindo Persada.

Pimay, Awaludin. 2005. Paradigma Dakwah Humanis, Strategi Dan Mrtode Dakwah Prof KH. Saifudin Zuhri. Semarang. Rasail.

Dradjat, Zakiah. dkk. 2006. Ilmu Pendidikan Islam Cet. VI. Jakarta. Bumi Aksara. 